question of infection, as that is generally recognised, but would point out that cats must not be overlooked as carriers. I am, Sirs, your faithfully, VERE G. WeBB, L.R.C.P. Irel. New Kent-road, S.E., Aug. 18th, 1897.

\section{A DISCLAIMER.}

\section{To the Editors of THE LANCET.}

Sirs, - Will you kindly allow me to state that I am not the Dr. Aveling who spoke at the Anarchist meeting in Trafalgar-square last Sunday?

I am, Sirs, yours faithfully,

Charles T. AVeling, M.S., M.D. Lond.

Cedar House, Stamford-hill, N., Aug. 25th, 1897.

\section{UNQUALIFIED ASSISTANTS.}

\section{To the Editors of THE LANCET.}

SIRs,-The perennial question of the unqualified assistant has again elevated its head. Without raising the many vexed issues which have been argued with such acerbity I would venture to draw attention to one class of unqualified practitioners which has not received adequate notice. I am a medical practitioner living in a very highly rated parish in West London. If an accident occurs within a few yards of my door, and the victim falls into the hands of the police, he or she is at once "treated" in accordance either with the preconceived notions of surgery of the active and intelligent constable or with such knowledge as First Aid learning may have imparted. But it appears to be a canon with the force to aroid calling in qualified medical aid where by any possible means this can be done. Should any unfortunate result accrue to the patient no notice is taken of the fact that the preliminary treatment was applied not merely by an unqualified bat by an amateur surgeon. If, on the other hand, the patient were brought to my surgery, and by any chance in my absence were to be attended by an unqualified assistant, skilful and as perfectly competent as many men in practice, and any mischance of whatever kind eventuated, an outcry would at once have been raised as to the employment of the unqualified assistant. There is also a further view of the case. Departmental ideas, whether local or otherwise, upon this subject do not always synchronise with the practice of the departments. To take a concrete case. On the Saturday preceding Bank Holiday my unqualified assistant saw a case which proved to be scarlet fever. $\mathrm{He}$ immediately referred the matter to me, and I, diagnosing the case, informed the parents that it required either isolation or removal to hospital, giving them, of course, the option, but informing them that in any case I must notify it. I notified it; but though I am to a certain extent anticipating, I may say that my notification, posted in due observance of the law on the Sunday, was received and opened only on Tuesday morning. In view of possible complications which might have arisen, and also in view of some which did arise recently in a somewhat similar case in which I was to a certain extent-by implication, at least-concerned, I took measures to have the case removed at once. The curious part of the whole matter is that the medical officer of health who took high ground recently when the unqualified assistant question was a feature in the case, but where his own department was proved to demonstration to be utterly and hopelessly in the wrong, has now left the professional work of his department to an unqualified assistant. Wanting information as to the propriety of notifying certain doubtful cases in connexion with a very high death-rate (about 70 per 1000 ), I was told I could not see the medical officer till his return from a six weeks' holiday, but I might see his chief clerk. I draw no inference. I enclose my card.

Aug. 24th, 1897. I am, Sirs, yours faithfully,

a QUalified PRactitiongr.

IT has been decided by the committee of management of the Westminster Hospital to entirely close their out-patients' department for the purpose of renovation and repairs, from Aug. 23rd to Sept. 18th, both days inclusive. The out-patient department of the Royal Free Hospital is also closed until Sept. 1st, and St. Mary's Hospital is entirely closed until the end of September

\section{THE BRUSSELS INTERNATIONAL EXHIBITION.}

(From a Special Commissioner.)

WHAT with numerous congresses, the exhibition, and the fine weather, Brussels is crowded with visitors. The town looks all the more animated as the authorities have decoratod the main streets leading to the exhibition with festoons, flags, banners, some gilt plaster statues, and coloured electric lights. Twice or three times a week there are illuminations. Under these circumstances it is not surprising that many persons have selected to spend a part of their holidays at Brassels. The exhibition is, of course, small when compared with the great international exhibitions of Paris, but it is large enough to thoroughly exhaust the visitor, especially if he desires to see everything in the course of two or three visits. It is large enough also to comprise an important section devoted to hygiene and a good many exhibits of surgical instruments and pharmacentical products. The members of the profession, therefore, who visit Brussels may combine utility with pleasure, for they will find at the exhibition several things of technical interest. Unlike many other exhibitions, that of Brussels is of easy access. The town is admirably provided with a network of electric and ordinary trains, so that speaking generally the exhibition can be reached with little waiting or crowding and at but small expense.

On entering the grounds by turning to the right the visitor reaches the main building through a number of minor strac* tures, which are, for the most part, cafés and restaurants, where, and also in contra-distinction to other exhibitions, meals can be obtained at moderate cost. Behind these there is a small oriental bazaar, where the sounds of wild Arab. music are to be heard and Moorish women dance. On the way to the main building there is also a separate and large circular structure, occupied exclusively by the French food section. Here may be seen how the French have imitated English biscuit manufactories, how the trade in preserved and tinned meats and regetables has been developed, and there are also specimens of olive oil, wines, cognacs, \&c.

Entering the main building by one of the smaller doors close at hand, and which is inscribed Bosnia and Herze. govina, the visitor is at once in the Austro-Hungarian section, and can note what care has been taken to develop these Serb provinces, now annexed by the Austrian Empire. On the walls large paintings give some idea of the beautiful scenery of these provinces, and show that they are likely to become favourite resorts for future tourists. Of the artistic products of Austrian industry-glass, pottery, carpets, furniture, and fancy articles-I need not spealin It is known that the artiole de Paris is often made in Vienna, and I allude to this section merely to say that the section of hygiene is situated immediately behind. The exhibits of the Ghent Bacteriological Institute dea? principally with the analysis of meat and the bacteria found in some ham which had cansed an epidemic in 1895. There are photographs of varions animals taken after injections of an infusion of this meat. On the same spot the Belgian. Temperance Society makes a brave show of sensational pictures and sections of the human liver so as to forcibly illustrate the evils of alcoholism. Then there are various models of masks to be worn by workmen engaged is dangerous industries, while the Belgian manufacturers of surgical instruments show how they apply antiseptic principles. For the operating-room furniture they seem to prefer copper or brass to nickel. Stools for the operating surgeons are made like piano stools, screwing up or down. The seat is a round concave sheet of brass, and the leg is partly brass and partly nickel. The tables, shelves, \&c., are, of course, of plate-glass. To the operating table can be affixed a carefully cast copper seat that can be passed under the patient's back so as to raise the pelvic region while the subject is still lying down. The sanitarian will be interested to note in this section hor Belgian manufacturers have imitated the well-known modals of English drain-pipes, traps, \&c., including methods for applying the smoke-test to household drains. There are also some Belgian pharmacentical specialities and a carriage used by the Brassels town authorities for conveying the insane. It is in the shape of a small omnibus, and the front 